\title{
Correction: Global health security: where is the data to inform health system strengthening?
}

Abimbola S, Topp SM, Palagyi A, et al. Global health security: where is the data to inform health system strengthening? BMJ Glob Health 2017;2:e000481.

This article has been corrected since it first published online. The middle initial of the second author has been added and her affiliation changed.

Open Access This is an Open Access article distributed in accordance with the Creative Commons Attribution Non Commercial (CC BY-NC 4.0) license, which permits others to distribute, remix, adapt, build upon this work non-commercially, and license their derivative works on different terms, provided the original work is properly cited and the use is non-commercial. See: http://creativecommons.org/licenses/by-nc/4.0/

(C) Article author(s) (or their employer(s) unless otherwise stated in the text of the article) 2017. All rights reserved. No commercial use is permitted unless otherwise expressly granted.

BMJ Glob Health 2017;2:e000481corr1. doi:10.1136/bmjgh-2017-000481corr1

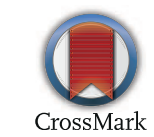

